\title{
Antibiotic Resistance Genes Dynamics at the Different Stages of the Biological Process in a Full-Scale Wastewater Treatment Plant ${ }^{\dagger}$
}

\author{
Ioanna Zerva 1, Ioanna Alexandropoulou ${ }^{2}$, Maria Panopoulou ${ }^{2}$, Paraschos Melidis ${ }^{1}$ and \\ Spyridon Ntougias ${ }^{1, *}$ \\ 1 Laboratory of Wastewater Management and Treatment Technologies, \\ Department of Environmental Engineering, Democritus University of Thrace, Vas. Sofias 12, \\ 67100 Xanthi, Greece; izerva@env.duth.gr (I.Z.); pmelidis@env.duth.gr (P.M.) \\ 2 Microbiology Laboratory, Medical School, Democritus University of Thrace, Campus (Dragana), \\ 68100 Alexandroupolis, Greece; ialexand@med.duth.gr (I.A.); mpanopou@med.duth.gr (M.P.) \\ * Correspondence: sntougia@env.duth.gr; Tel.: +30-25410-79313 \\ + Presented at the 3rd EWaS International Conference on "Insights on the Water-Energy-Food Nexus", \\ Lefkada Island, Greece, 27-30 June 2018.
}

Published: 30 July 2018

\begin{abstract}
Wastewater treatment plants (WWTPs) highly contribute to the transmission of antibiotic resistance genes (ARGs) in the environment. In this work, the diversity of ermF, ermB, sul1 and int1-enconding genes was examined in the influent, the mixed liquor and the effluent of a full-scale WWTP. Based on the clones analyzed, similar genotypes were recorded at all process stages. However, distinct genotypes of int 1 were responsible for the expression of sul1 and ermF genes in Gammaproteobacteria and Bacteroidetes, respectively. Due to the detection of similar ARGs profiles throughout the biological process, it is concluded that additional treatment is needed for their retention.
\end{abstract}

Keywords: antibiotic resistance genes; microbiological effluent quality; biological processes; environmental monitoring; wastewater treatment

\section{Introduction}

The main source of antibiotics in the environment is the excretion of incompletely metabolized antibiotics by humans and animals. Thus, WWTPs are important reservoirs of antibiotic resistant bacteria, transmitting them into the aquatic ecosystems [1].

There are several studies examining the effectiveness of the different stages of the treating processes at reducing the concentrations of various antibiotics. Lin et al. [2] determined the effectiveness of primary and secondary treatment process, which was followed by a disinfection step, on the reduction of sulfonamides, cephalosporins, quinolones and macrolides. Batt et al. [3] studied the fate of four different antibiotics belonging to quinolones, sulfonamides and tetracyclines, during their treatment in four WWTPs, which differed in design and operating conditions. Moreover, Li and Zhang [4] and Watkinson et al. [5] recorded concentration removals within 25 and $80 \%$ during treatment of antibiotics in conventional treatment plants.

Despite that WWTPs are suitable for reducing the concentrations of pollutants in municipal wastewater, they appear to be insufficient in reducing antibiotic gene content [6]. By contrast, the activated sludge of municipal wastewater treatment plants is an ideal environment for the proliferation of antibiotic resistance genes since ARGs transmission can occur within the diverse microbial species of the flocs $[7,8]$. For instance, tetracycline, sulfonamide, macrolide and quinolone 
resistance genes (tet, sul, erm, and $q n r$, respectively) have been detected in the treated effluent of WWTPs [9]. Moreover, Chen and Zhang [10] detected low number of copies of the sulfonamide antibiotic resistance genes sul1 and sul2, and the integrase 1 gene (int1) in the effluent of certain WWTPs. The same authors reported a strong correlation within the amount of sul1 and int1 genes, indicating the involvement of integrase in sul1 gene transmission [10].

Thus, the current study was conducted to investigate the distribution of antibiotic resistance genes (ARGs) in a sewage treatment plant, based on the molecular identification of three antibiotic resistance genes, i.e., sul1, ermB and ermF, and the integrase 1 gene (int1), which favors the spread of multiple genes to the microbial constituents of the activated sludge.

\section{Materials and Methods}

Samples from the influent, the mixed liquor and the effluent of WWTP were obtained by using sterile glass bottles. Genomic DNA extraction was conducted based on commercially available kit (Vivantis, Selangor Darul Ehsan, Malaysia). The macrolide (i.e., ermB and ermF) and the sulfonamide (i.e., sul1) resistance genes as well as the class 1 integron integrase (int1) genes were amplified by the use of the primer pairs erm(B)-454rc/erm(B)-91fc, erm(F)-189f/erm(F)-497r, sul1-F/sul1-B and int1-F/int1-R, respectively [11,12]. The amplification reaction was carried out in a TaKaRa Dice TP600 PCR thermocycler (Japan). The amplicons obtained were ligated into the bacterial vector pGEM-T Easy (Promega, Madison, WI, USA), and the recombinant DNA were transformed into DH5a competent cells. The plasmid DNA was extracted by the Vivantis plasmid kit (Malaysia) from the recombinant Escherichia coli cultures, and sequencing of the PCR inserts was performed at Macrogen using primers SP6 and T7 (Promega). The closest relatives of the amplicons obtained were subjected to BLAST searches. The amplified gene sequences and their closest relatives were translated to amino-acids by Emboss Transeq [13] and aligned by the Clustal Omega bioinformative tool [14].

\section{Results and Discussion}

A total of twelve clone libraries were constructed, each one for any antibiotic resistance gene and sampling point examined, i.e., the influent, the mixed liquor and the effluent of the full-scale WWTP. In the case of macrolides, the screening of ermB gene clone libraries resulted in the identification of three distinct genotypes. The major genotype consisting of 19 clones, which were identical to known sequences deposited in the International Sequencing database, while the second genotype comprised of 3 clones. Interestingly, the last genotype consisted of a single clone, which was only detected in the effluent of WWTP. On the other hand, the two major genotypes were detected throughout the whole biological treatment, a fact that indicates dispersion of this gene throughout the processing. The major ermB gene genotype showed high genetic relationship with respective genes carried out by strains of the genera Streptococcus, Nocardia, Staphylococcus, Clostridium, Lactococcus and Listeria (Table 1). Based on protein level analysis, the ermB genes detected were responsible for encoding a protein consisting of 107 amino acids, where similar gene translation patterns were identified. In comparison to other studies, Lee et al. [15] detected ermB genes in the effluent of two WWTPs, even after UV application as the disinfection method. Moreover, Wang et al. [6] showed the ineffectiveness of WWTPs in the removal of antimicrobial resistant genes, which were prevailing in all samples analyzed.

Regarding the detection of ermF genes in the WWTP examined, three distinct clone groups were identified, with the major clone cluster being consisted of 17 members. The ermF genes of the three genotypes were differentiated up to three nucleotide bases. It was also observed that the second group of ermF gene clones showed a close genetic relationship with the members of the first group and therefore, it could be considered as a subgroup of the dominant genotype. This led us to the conclusion that the dominant genotype of the ermF gene was detected throughout the biological treatment process. Although the third genotype consisted only of 3 clones, such genetic pattern was detected throughout the whole biological process. At protein level, only two distinct amino-acid patterns were identified as the result of the close relationship within the members of the first and the 
second genotype. Almost all microorganisms carrying the ermF gene showed high genetic relation with respective genes detected only in members of the phylum Bacteroidetes, except of the gammaproteobacterium Bibersteinia trehalosi (Table 2). In comparison to other studies, Fahrenfeld et al. [16] detected ermF genes in the reclaimed water derived from a WWTP. Based on metagenomic analysis, Szczepanowski et al. [17] reported the prevalence of ermF gene in both activated sludge and the treated effluent of a WWTP.

Table 1. Identification of the major ermB genotypes in the WWTP examined.

\begin{tabular}{|c|c|c|c|}
\hline Genotype & Gene Similarity & Microorganism Carrying the Closest Relative ermB Gene & GenBank Code \\
\hline \multirow{13}{*}{1} & \multirow{13}{*}{$100 \%$} & Streptococcus pneumoniae ICESpnIC1 & HG799494 \\
\hline & & Nocardia farcinica CNM20080087 & KM194594 \\
\hline & & Streptococcus agalactiae GBS6 & СР007572 \\
\hline & & Staphylococcus aureus SA268 & СР006630 \\
\hline & & Clostridium difficile transposon Tn6218 & HG002387 \\
\hline & & Listeria monocytogenes LM78 & JX535233 \\
\hline & & Enterococcus faecium e82 & JN899594 \\
\hline & & Enterococcus faecalis plasmid pLG2 & NG_041215 \\
\hline & & Lactococcus garvieae plasmid pKL0018 & AB290882 \\
\hline & & Streptococcus uberis & EF540938 \\
\hline & & Bacillus cereus 363 & AF480455 \\
\hline & & Streptococcus agalactiae KMP104 & DQ355148 \\
\hline & & Staphylococcus lentus & SLU35228 \\
\hline \multirow{18}{*}{2} & \multirow{18}{*}{$99 \%$} & Streptococcus pneumoniae NT_110_5 & СР007593 \\
\hline & & Streptococcus pyogenes HKU360 & СР009612 \\
\hline & & Enterococcus faecium Aus0085 plasmid p3 & СР006623 \\
\hline & & Streptococcus oligofermentans AS 1.3089 & СР004409 \\
\hline & & Streptococcus suis D12 & СР002644 \\
\hline & & Staphylococcus pseudintermedius C2597 & JF909978 \\
\hline & & Streptococcus uberis FSL Z3-097 & EF539836 \\
\hline & & Pediococcus acidilactici plasmid pEOC01 & DQ220741 \\
\hline & & Lactobacillus johnsonii G41 PEP-PTS & DQ518904 \\
\hline & & Streptococcus cristatus transposon Tn6002 & AY898750 \\
\hline & & Streptococcus hyointestinalis & AY278215 \\
\hline & & Lactobacillus fermentum & NG_034736 \\
\hline & & Peptoclostridium difficile 630 & СР010905 \\
\hline & & Campylobacter jejuni $\mathrm{C} 179 \mathrm{~b}$ & KF864551 \\
\hline & & Escherichia coli ECONIH1 plasmid pECO-824 & СР009860 \\
\hline & & Campylobacter coli SH-CCD11C365 & KC876752 \\
\hline & & Enterococcus thailandicus W3 plasmid pW3 & NG_041564 \\
\hline & & Lactobacillus plantarum plasmid pLFE1 & FJ374272 \\
\hline \multirow{12}{*}{3} & \multirow{12}{*}{$99 \%$} & Bacteroides uniformis transposon WH207 & AY345595 \\
\hline & & Enterococcus faecium plasmid pXD5 & KJ645709 \\
\hline & & Staphylococcus hyicus plasmid pSTE1 & HE662694 \\
\hline & & Staphylococcus aureus SA7037 plasmid pV7037 & NG_041616 \\
\hline & & Enterococcus faecalis plasmid pTW9 & AB563188 \\
\hline & & Lactococcus garvieae plasmid pKL0018 & AB290882 \\
\hline & & Streptococcus suis $2-22$ & EU047808 \\
\hline & & Streptococcus uberis FSL Z3-102 & EF539835 \\
\hline & & Arcanobacterium pyogenes & AY334073 \\
\hline & & Staphylococcus intermedius MLS-17 & AF239773 \\
\hline & & Enterococcus hirae & AF406971 \\
\hline & & Campylobacter jejuni $\mathrm{C} 179 \mathrm{~b}$ & KF864551 \\
\hline
\end{tabular}

Regarding sulfonamides resistance genes, there was a dominant cluster consisting of 23 over 24 clones analyzed (carrying the sul1 gene). The single representative of the second genotype possessed a distinct genetic position as compared to the dominant genotype, where genetic distance was greater than 4 base pairs. However, at protein level, its amino-acid sequence was similar with the major sul1 cluster. Most of the microorganisms, which carried the sul1 gene, exhibited high genetic similarity with sul1 genes detected in strains of the class Gammaproteobacteria (Table 3). In the studies of Ben et al. [7] and Du et al. [18], sul1 genes were the most abundant gene among the ARGs 
examined in various WWTPs. Moreover, Lupan et al. [19] confirmed the spread of sul1 genes in a river $10 \mathrm{~km}$ downstream of a WWTP.

Table 2. Identification of the major ermF genotypes in the WWTP examined.

\begin{tabular}{cclc}
\hline Genotype & Gene Similarity & Microorganism Carrying the Closest Relative Ermf Gene & GenBank Code \\
\hline 1 & $100 \%$ & Bacteroides ovatus MN11 & HE999703 \\
\hline \multirow{3}{*}{$100 \%$} & Riemerella anatipestifer RA-CH-1 & CP003787 \\
& Bacteroides salanitronis DSM 18170 & CP002530 \\
& Bibersteinia trehalosi USDA-ARS-USMARC-189 & CP006955 \\
& Barnesiella viscericola DSM 18177 & CP007034 \\
& Capnocytophaga sputigena Be58 & JQ707297 \\
& Bacteroides thetaiotaomicron transposon CTnDOT & AJ311171 \\
\hline \multirow{3}{*}{3} & Bacteroides salanitronis DSM 18170 & CP002530 \\
& Bibersteinia trehalosi USDA-ARS-USMARC-189 & CP006955 \\
& Barnesiella viscericola DSM 18177 & CP007034 \\
& Bacteroides ovatus MN11 & HE999703 \\
& & Capnocytophaga sputigena Be58 & JQ707297 \\
& & Bacteroides thetaiotaomicron transposon CTnDOT & AJ311171 \\
\hline
\end{tabular}

Table 3. Identification of the major sul1 genotypes in the WWTP examined.

\begin{tabular}{|c|c|c|c|}
\hline Genotype & Gene Similarity & Microorganism Carrying the Closest Relative sul1 Gene & GenBank Code \\
\hline \multirow{17}{*}{1} & \multirow{17}{*}{$100 \%$} & Aeromonas hydrophila AL06-06 & СР010947 \\
\hline & & Vibrio parahaemolyticus V36 plasmid pVPH1 & KР688397 \\
\hline & & Acinetobacter baumannii AB_NCGM 346 & LC030435 \\
\hline & & Escherichia coli 6409 plasmid p6409 & СР010373 \\
\hline & & Pseudomonas aeruginosa NCGM257 & AP014651 \\
\hline & & Klebsiella pneumoniae ATCC BAA-2146 plasmid pNDM-US-2 & KJ588779 \\
\hline & & Serratia marcescens 11663 plasmid p11663 & AP014611 \\
\hline & & Salmonella enterica plasmid pSBLT & LN794247 \\
\hline & & Vibrio cholerae plasmid pRJ354C & КР076293 \\
\hline & & Proteus mirabilis PEL & KF856624 \\
\hline & & Enterobacter cloacae 34983 plasmid p34983 & СР010378 \\
\hline & & Pantoea sp. PSNIH1 plasmid pPSP-a3e & СР009883 \\
\hline & & Proteus mirabilis PmC162 & KJ186154 \\
\hline & & Stenotrophomonas maltophilia GZP-Sm1 & KM649682 \\
\hline & & Klebsiella oxytoca MS5279 plasmid pKOI-34 & AB715422 \\
\hline & & Aeromonas salmonicida 2004-05MF26 plasmid pSN254b & KJ909290 \\
\hline & & Nocardia nova CNM20121076 & KM194585 \\
\hline \multirow{14}{*}{2} & \multirow{14}{*}{$99 \%$} & Aeromonas hydrophila AL06-06 & СР010947 \\
\hline & & Vibrio parahaemolyticus V36 plasmid pVPH1 & KР688397 \\
\hline & & Acinetobacter baumannii AB_NCGM 346 & LC030435 \\
\hline & & Escherichia coli O157:H16 strain Santai & СР007592 \\
\hline & & Pseudomonas aeruginosa NCGM257 & AP014651 \\
\hline & & Klebsiella pneumoniae ATCC BAA-2146 plasmid pNDM-US-2 & KJ588779 \\
\hline & & Serratia marcescens 11663 plasmid p11663 & AP014611 \\
\hline & & Salmonella enterica plasmid pSBLT & LN794247 \\
\hline & & Vibrio cholerae plasmid pRJ354C & КР076293 \\
\hline & & Proteus mirabilis PmCHE & KJ439039 \\
\hline & & Stenotrophomonas maltophilia GZP-Sm1 & KM649682 \\
\hline & & Klebsiella oxytoca MS5279 plasmid pKOI-34 & AB715422 \\
\hline & & Aeromonas salmonicida 2004-05MF26 plasmid pSN254b & KJ909290 \\
\hline & & Nocardia nova CNM20121076 & KM194585 \\
\hline
\end{tabular}

Considering the genetic analysis of integrase class 1 gene, a prevalent clone cluster was detected, which included 25 out of 26 clones analyzed. Nevertheless, at protein level, these integrase class 1 clusters differed by a single amino acid. Interestingly, the microbial species of the major genotype carrying the int 1 gene were related to those carrying sul1 genes. On the other hand, the 
bacterial strain possessing the int1 gene of the minor cluster was associated with microbiota carrying ermF genes (Table 4). A strong correlation between the concentrations of sul1 and int 1 genes have been recently reported $[6,7,18]$, which demonstrates the importance of integrons in the spread of these antibiotic resistance genes in the environment, indicating that sul1 gene is frequently located on class 1 integron.

Table 4. Identification of the major int1genotypes in the WWTP examined.

\begin{tabular}{|c|c|c|c|}
\hline Genotype & Gene Similarity & Microorganism Carrying the Closest Relative int1 Gene & GenBank Code \\
\hline \multirow{20}{*}{1} & \multirow{20}{*}{$100 \%$} & Aeromonas hydrophila sAL06-06 & СР010947 \\
\hline & & Klebsiella pneumoniae Kpn-3002cz plasmid pS-300cz & KJ958927 \\
\hline & & Vibrio parahaemolyticus V36 plasmid pVPH1 & KР688397 \\
\hline & & Acinetobacter baumannii & LC030435 \\
\hline & & Escherichia coli 6409 plasmid p6409 & СР010373 \\
\hline & & Pseudomonas aeruginosa NCGM257 & AP014651 \\
\hline & & Achromobacter xylosoxidans A22732 plasmid pA22732-IMP & KJ588780 \\
\hline & & Klebsiella pneumoniae ATCC BAA-2146 plasmid pNDM-US-2 & KJ588779 \\
\hline & & Serratia marcescens 11663 plasmid p11663 & AP014611 \\
\hline & & Salmonella enterica plasmid incHI2 & LN794248 \\
\hline & & Acinetobacter baumannii $\mathrm{A} 1$ & СР010781 \\
\hline & & Vibrio cholerae plasmid pRJ354C & КР076293 \\
\hline & & Proteus mirabilis PEL & KF856624 \\
\hline & & Enterobacter cloacae 34983 plasmid p34983 & СР010378 \\
\hline & & Serratia marcescens A4Y201 plasmid pG5A4Y201 & KJ541069 \\
\hline & & Klebsiella oxytoca MS5279 plasmid pKOI-34 & AB715422 \\
\hline & & Nocardia veterana CNM20120791 & KM194583 \\
\hline & & Shigella flexneri Shi06HN006 & СР004057 \\
\hline & & Proteus mirabilis PmCHE & KJ439039 \\
\hline & & Klebsiella pneumoniae blaNDM-1 plasmid 1 & СР009116 \\
\hline \multirow{7}{*}{2} & \multirow{7}{*}{$99 \%$} & Bacteroides salanitronis DSM 18170 & СР002530 \\
\hline & & Bibersteinia trehalosi USDA-ARS-USMARC-189 & СР006955 \\
\hline & & Barnesiella viscericola DSM 18177 & СР007034 \\
\hline & & Bacteroides ovatus MN11 & HE999703 \\
\hline & & Bibersteinia trehalosi USDA-ARS-USMARC-192 & СР003745 \\
\hline & & Capnocytophaga sputigena Be58 & JQ707297 \\
\hline & & Bacteroides thetaiotaomicron transposon CTnDOT & AJ311171 \\
\hline
\end{tabular}

\section{Conclusions}

Based on the molecular determination of sul1, ermB, ermF and int1 genes, it is concluded that antibiotic resistant genes spread occurred throughout the biologic process in WWTPs. The similar genotyping profiles detected in the influent and the effluent point out the necessity for the implementation of effective tertiary treatment methods, regarding gene removal from the treated effluent. Further experiments on the use of advanced oxidation systems and membrane technologies will elucidate issues regarding the removal of antibiotic resistance genes. Moreover, different class 1 integrons appeared to be responsible for the transmission of sul1 and ermF genes among members of distinct phyla, a fact that indicates a microbial specificity in antibiotic resistant gene transmission.

Author Contributions: I.Z. and I.A. performed the experiments; I.Z., S.N., P.M., I.A. and M.P. analyzed the data; I.Z. and S.N. wrote the paper; S.N. conceived and designed the experiments.

Conflicts of Interest: The authors declare no conflict of interest.

\section{References}

1. Kumar, A.; Pal, D. Antibiotic resistance and wastewater: Correlation, impact and critical human health challenges. J. Environ. Chem. Eng. 2018, 6, 52-58, doi:10.1016/j.jece.2017.11.059.

2. Lin, A.Y.-C.; Yu, T.-H.; Lateef, S.K. Removal of pharmaceuticals in secondary wastewater treatment processes in Taiwan. J. Hazard. Mater. 2009, 167, 1163-1169, doi:10.1016/j.jhazmat. 2009.01.108. 
3. Batt, A.L.; Kim, S.; Aga, D.S. Comparison of the occurrence of antibiotics in four full-scale wastewater treatment plants with varying designs and operations. Chemosphere 2007, 68, 428-435, doi:10.1016/j.chemosphere.2007.01.008.

4. Li, B.; Zhang, T. Mass flows and removal of antibiotics in two municipal wastewater treatment plants. Chemosphere 2011, 83, 1284-1289, doi:10.1016/j.chemosphere.2011.03.002.

5. Watkinson, A.J.; Murby, E.J.; Costanzo, S.D. Removal of antibiotics in conventional and advanced wastewater treatment: Implications for environmental discharge and wastewater recycling. Water Res. 2007, 41, 4164-4176, doi:10.1016/j.watres.2007.04.005.

6. Wang, M.; Shen, W.; Yan, L.; Wang, X.-H.; Xu, H. Stepwise impact of urban wastewater treatment on the bacterial community structure, antibiotic contents, and prevalence of antimicrobial resistance. Environ. Pollut. 2017, 231, 1578-1585, doi:10.1016/j.envpol.2017.09.055.

7. Ben, W.; Wang, J.; Cao, R.; Yang, M.; Zhang, Y.; Qiang, Z. Distribution of antibiotic resistance in the effluents of ten municipal wastewater treatment plants in China and the effect of treatment processes. Chemosphere 2017, 172, 392-398, doi:10.1016/j.chemosphere.2017.01.041.

8. Neudorf, K.D.; Huang, Y.N.; Ragush, C.M.; Yost, C.K.; Jamieson, R.C.; Truelstrup Hansen, L. Antibiotic resistance genes in municipal wastewater treatment systems and receiving waters in Arctic Canada. Sci. Total Environ. 2017, 598, 1085-1094, doi:10.1016/j.scitotenv.2017.04.151.

9. Di Cesare, A.; Eckert, E.M.; D’Urso, S.; Bertoni, R.; Gillan, D.C.; Wattiez, R.; Corno, G. Co-occurrence of integrase 1, antibiotic and heavy metal resistance genes in municipal wastewater treatment plants. Water Res. 2016, 94, 208-214, doi:10.1016/j.watres.2016.02.049.

10. Chen, H.; Zhang, M. Occurrence and removal of antibiotic resistance genes in municipal wastewater and rural domestic sewage treatment systems in eastern China. Environ. Int. 2013, 55, 9-14, doi:10.1016/j.envint.2013.01.019.

11. Kerrn, M.B.; Klemmensen, T.; Frimodt-Möller, N.; Espersen, F. Susceptibility of Danish Escherichia coli strains isolated from urinary tract infections and bacteraemia, and distribution of sul genes conferring sulphonamide resistance. J. Antimicrob. Chemother. 2002, 50, 513-516, doi:10.1093/jac/dkf164.

12. Chen, J.; Yu, Z.; Michel, F.C., Jr.; Wittum, T.; Morrison, M. Development and application of real-time PCR assays for quantification of erm genes conferring resistance to macrolides-lincosamides-streptogramin $\mathrm{B}$ in livestock manure and manure management systems. Appl. Environ. Microbiol. 2007, 73, 4407-4416, doi:10.1128/AEM.02799-06.

13. EMBOSS Transeq. Available online: https://www.ebi.ac.uk/Tools/st/emboss_transeq/(accessed on 15 February 2018).

14. Sievers, F.; Wilm, A.; Dineen, D.; Gibson, T.J.; Karplus, K.; Li, W.; Lopez, R.; McWilliam, H.; Remmert, M.; Söding, J.; et al. Fast, scalable generation of high-quality protein multiple sequence alignments using Clustal Omega. Mol. Syst. Biol. 2011, 7, 539, doi:10.1038/msb.2011.75.

15. Lee, J.; Jeon, J.H.; Shin, J.; Jang, H.M.; Kim, S.; Song, M.S.; Kim, Y.M. Quantitative and qualitative changes in antibiotic resistance genes after passing through treatment processes in municipal wastewater treatment plants. Sci. Total Environ. 2017, 605-606, 906-914, doi:10.1016/j.scitotenv.2017.06.250.

16. Fahrenfeld, N.; Ma, Y.; O'Brien, M.; Pruden, A. Reclaimed water as a reservoir of antibiotic resistance genes: Distribution system and irrigation implications. Front. Microbiol. 2013, 4, 130, doi:10.3389/fmicb.2013.00130.

17. Szczepanowski, R.; Linke, B.; Krahn, I.; Gartemann, K.-H.; Gützkow, T.; Eichler, W.; Pühler, A.; Schlüter, A. Detection of 140 clinically relevant antibiotic-resistance genes in the plasmid metagenome of wastewater treatment plant bacteria showing reduced susceptibility to selected antibiotics. Microbiology 2009, 155, 2306-2319, doi:10.1099/mic.0.028233-0.

18. Du, J.; Ren, H.; Geng, J.; Zhang, Y.; Xu, K.; Ding, L. Occurrence and abundance of tetracycline, sulfonamide resistance genes, and class 1 integron in five wastewater treatment plants. Environ. Sci. Pollut. Res. 2014, 21, 7276-7284, doi:10.1007/s11356-014-2613-5.

19. Lupan, I.; Carpa, R.; Oltean, A.; Kelemen, B.S.; Popescu, O. Release of antibiotic resistant bacteria by a waste treatment plant from Romania. Microbes Environ. 2017, 32, 219-225, doi:10.1264/ jsme2.ME17016.

(C) 2018 by the authors. Licensee MDPI, Basel, Switzerland. This article is an open access article distributed under the terms and conditions of the Creative Commons Attribution (CC BY) license (http://creativecommons.org/licenses/by/4.0/). 